\title{
THE GROWTH OF INFANT MICE AT TWO TEMPERATURES
}

\author{
S. A. BARNETT* AND ALEXANDRA G. NEIL \\ Department of Zoology, University of Glasgow \\ (Received 30th March 1971, accepted 23rd April 1971)
}

Summary. Mice, Mus musculus, were bred in permanently mated pairs, in two environments, at $21^{\circ} \mathrm{C}$ and $-3^{\circ} \mathrm{C}$, respectively. Observations on strain $\mathrm{A} 2 \mathrm{G} / \mathrm{Tb}$ are described in detail; others studied were strain $\mathrm{C} 57 \mathrm{BL} / \mathrm{Tb}$, outbred laboratory mice, and wild mice bred in the laboratory.

Second to fourth litters were observed at birth, 10 days and 21 days. Most deaths were due to losses of whole litters. Mortality was higher at $-3^{\circ} \mathrm{C}$ than at $21^{\circ} \mathrm{C}$, but not among $\mathrm{A} 2 \mathrm{G} / \mathrm{Tb}$ mice of a stock bred for many generations in the cold.

Litter weights at birth, for a given litter size, were unaffected by cold, but there were fewer large litters at $-3^{\circ} \mathrm{C}$ than at $21^{\circ} \mathrm{C}$; hence mean litter weight at birth was lower in the cold. At 10 and 21 days, litter weights, except those of strain $\mathrm{C} 57 \mathrm{BL} / \mathrm{Tb}$, were lower in the cold at most litter sizes.

Individual weight at 3 weeks was unaffected by number of litter mates at litter sizes around the mode, and declined only at high litter sizes; hence the sizes of most litters were within the range which allowed most growth.

The findings illustrate the importance of the uterine environment in determining litter size and survival in the nest.

\section{INTRODUCTION}

The growth of a mouse, Mus musculus, between birth and weaning is influenced by its genotype, the environment already experienced in the uterus and conditions in the nest. Among the components of the nest environment are the milk supply, other aspects of maternal performance, the number of litter mates, and the ambient temperature. Findings on mouse reproduction to the end of 1949 have been thoroughly reviewed by Grüneberg (1952); and the effects of low environmental temperature have been summarized by Barnett (1965). The account of litter and weaning weights that follows illustrates the interacting effects especially of number in litter and environmental temperature.

\section{MICE AND METHODS}

Four types of mice were studied : two were inbred strains, A2G/Tb and C57BL/

* Present address: Department of Zoology, Australian National University, Canberra, ACT 2600, Australia. 
$\mathrm{Tb}$; a third was a closed, outbred stock derived from $\mathrm{A} / \mathrm{Tb}, \mathrm{A} 2 \mathrm{G} / \mathrm{Tb}, \mathrm{C} 57 \mathrm{BL} /$ $\mathrm{Tb}$ and GFF mice; the fourth was a closed, outbred stock of wild house mice. Only the findings on the $\mathrm{A} 2 \mathrm{G} / \mathrm{Tb}$ mice are reported in detail.

The mice were bred in two environments, one kept at about $21^{\circ} \mathrm{C}$, the other at $-3^{\circ} \mathrm{C}$. The $\mathrm{A} 2 \mathrm{G} / \mathrm{Tb}$ mice at $-3^{\circ} \mathrm{C}$ were of two kinds: the 'new stock' were of the first or second generation raised in the cold; the 'old stock' were of the 18th to 25th generations bred continuously at the low temperature, and were better adapted to the cold (reviewed by Barnett, 1965). The C57BL/Tb mice at $-3^{\circ} \mathrm{C}$ were all of Generations 12 to 16 in the cold environment. The mixed stock had been bred for sixteen generations in each temperature, without deliberate selection. They had, however, undoubtedly changed genetically during that time (Barnett, 1965). The wild mice at $21^{\circ} \mathrm{C}$ were of the second generation reared in captivity; at $-3^{\circ} \mathrm{C}$, they were of the frst generation reared in captivity, and were transferred to $-3^{\circ} \mathrm{C}$ at mating.

At $21^{\circ} \mathrm{G}$, water was supplied in excess, in bottles; in the cold environment it was given as ice blocks which the mice licked (Stoddart, 1966). In other respects the conditions in the two environments were the same. Diet 41 (Bruce \& Parkes, 1949) was also always available. The cages were of metal with wire lids. The cage floors were covered with sawdust. Cotton wool was given for additional bedding. Both rooms were artificially lit for $12 \mathrm{hr}$ in each 24 . Other information about the conditions of the mice is given by Barnett (1956).

The adult laboratory mice were kept in permanently mated pairs from the age of 5 weeks to 28 weeks. The young were taken from their parents at 3 weeks. Only second, third and fourth litters were studied. New litters were looked for daily at about 10.00 hours, and weighed as a whole as soon as they were found; litters were also weighed as a whole at 10 days; at 3 weeks, about half the mice were also weighed individually; litters were omitted from individual weighing at random. All weighing was to the nearest of $0.1 \mathrm{~g}$ on a Mettler direct-reading, torsion balance. The procedure used for the wild mice is fully described by Barnett, Smart \& Stoddart (1971); their breeding was recorded for 2 years, that is, for their full reproductive span.

In the account below, each mean is accompanied by its standard error. Comparisons of means are by Student's $t$-test, two-tailed.

\section{RESULTS}

The $A 2 G / T b$ mice

Table 1 summarizes the observations on the $A 2 \mathrm{G} / \mathrm{Tb}$ mice. Mean litter size was only slightly reduced, in each of the three classes of mice, between birth and 21 days. An effect of cold was shown by the new-stock litters at birth, which were smaller than those of the controls $(P<0.001)$; but the litter size of the old stock was virtually the same as that of the controls. A further effect of cold was evident in new-stock litter weight, which showed a progressive effect of cold: at birth it was $68 \%$ of that of the controls; at 21 days, only $52 \%$. The old-stock litters diverged from the controls less, but were lighter at 21 days $(P<0.01)$. Text-figures 1 to 3 give more information on litter weights and sizes. At birth mean litter weights of all three classes were virtually the same at each litter size 
TABLE 1

LITTER NUMBER, SIZE AND WEIGHT OF A2G/Tb MICE

\begin{tabular}{|c|c|c|c|}
\hline & 0 days & 10 days & 21 days \\
\hline $\begin{array}{l}21^{\circ} \mathrm{C} \\
\text { No. of litters } \\
\text { Size } \\
\text { Weight }(\mathrm{g})\end{array}$ & $\begin{array}{c}126 \\
6 \cdot 5 \pm 0 \cdot 32 \\
10 \cdot 3 \pm 0 \cdot 29\end{array}$ & $\begin{array}{c}113 \\
6 \cdot 3 \pm 0 \cdot 21 \\
39 \cdot 2 \pm 1 \cdot 00\end{array}$ & $\begin{array}{c}112 \\
6 \cdot 2 \pm 0 \cdot 23 \\
62 \cdot 2 \pm 0 \cdot 16\end{array}$ \\
\hline $\begin{array}{l}-3^{\circ} \mathrm{C} \text { : Generation } 1 \\
\text { No. of litters } \\
\text { Size } \\
\text { Weight }(\mathrm{g})\end{array}$ & $\begin{array}{c}47 \\
4 \cdot 4 \pm 0.25 \\
7 \cdot 0 \pm 0 \cdot 48\end{array}$ & $\begin{array}{c}37 \\
4 \cdot 3 \pm 0 \cdot 21 \\
25 \cdot 2 \pm 1 \cdot 16\end{array}$ & $\begin{array}{c}35 \\
4 \cdot 1 \pm 0.22 \\
32 \cdot 6 \pm 1.94\end{array}$ \\
\hline $\begin{array}{c}-3^{\circ} \mathrm{G} \text { : Generations } \\
26 \text { to } 29 \\
\text { No. of litters } \\
\text { Size } \\
\text { Weight }(\mathrm{g})\end{array}$ & $\begin{array}{c}107 \\
6.4 \pm 0.21 \\
9.5 \pm 0.31\end{array}$ & $\begin{array}{c}100 \\
6 \cdot 2 \pm 0 \cdot 20 \\
37 \cdot 3 \pm 1 \cdot 25\end{array}$ & $\begin{array}{c}98 \\
6 \cdot 2 \pm 0 \cdot 20 \\
52 \cdot 1 \pm 1 \cdot 59\end{array}$ \\
\hline
\end{tabular}

Litter sizes and weights expressed as Mean \pm S.E.

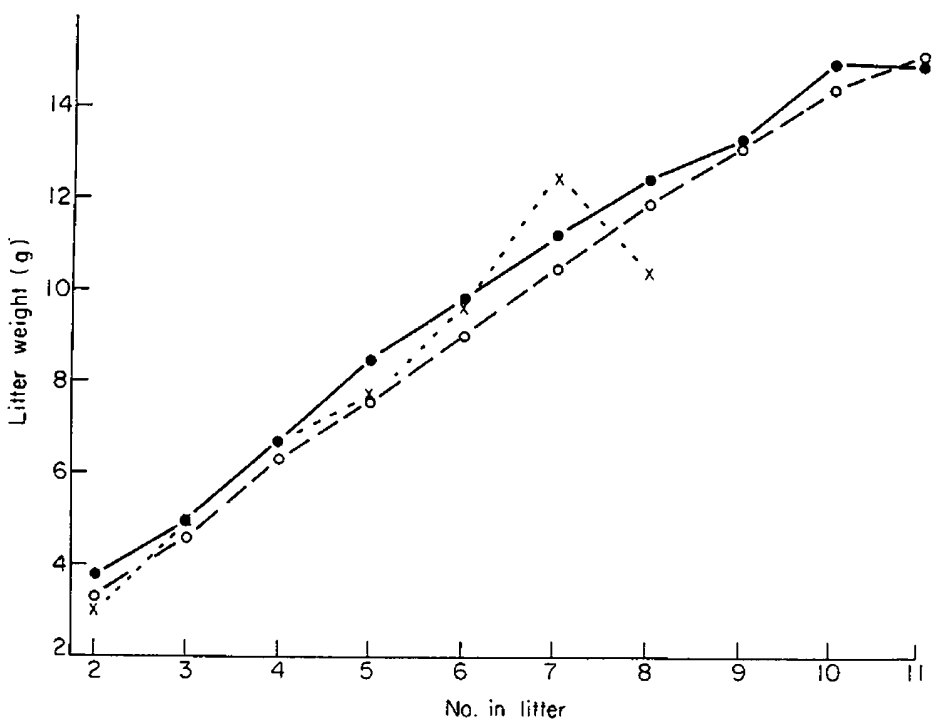

TEXT-FIG. 1. Mean litter weight at birth at each litter size: strain A2G/Tb mice, controls $\left(21^{\circ} \mathrm{C}\right)(0)$, old stock at $-3^{\circ} \mathrm{C}(0)$ and new stock at $-3^{\circ} \mathrm{C}(\times)$.

(Text-fig. 1); at 10 days (Text-fig. 2), the weights of the larger litters of the new stock diverged from those of the controls; at 21 days (Text-fig. 3), the divergence was more marked, and was also displayed by the old stock. There was a marked failure of the new stock to produce large litters.

Mortality (Table 2) was highest among the new stock, lowest among the old. Most deaths took place during the first 10 days of life. The great majority of deaths involved losses of whole litters: losses of individual young were few in all classes.

Table 3 gives mean individual weights of $A 2 G / T b$ mice at 3 weeks. The weights of the old stock illustrate the superiority of these mice over the new stock (cf. Barnett \& Widdowson, 1965). Comparing mean weights at or before 


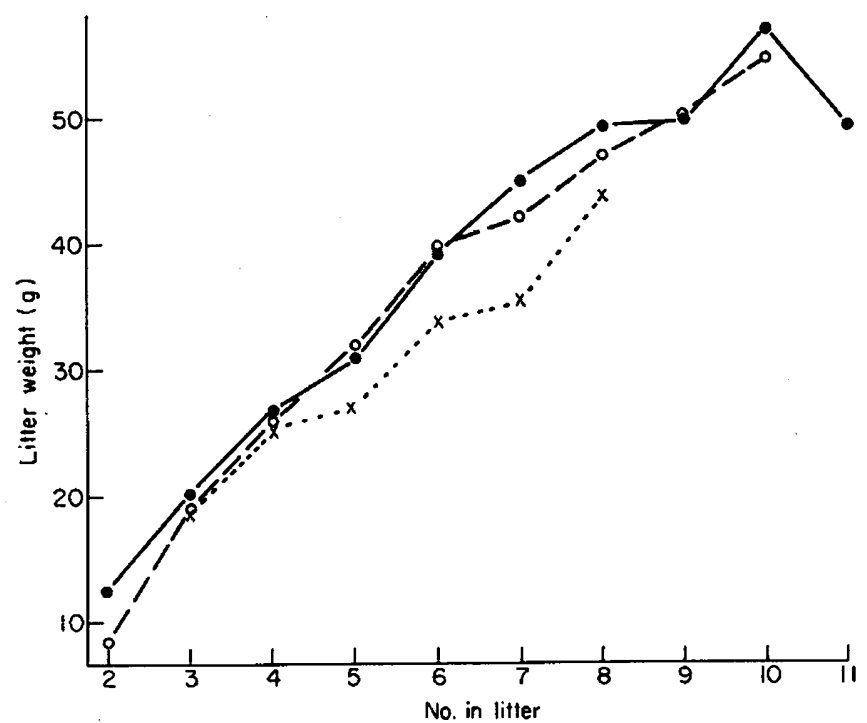

Text-Fic. 2. As Text-fig. 1, litters aged 10 days.

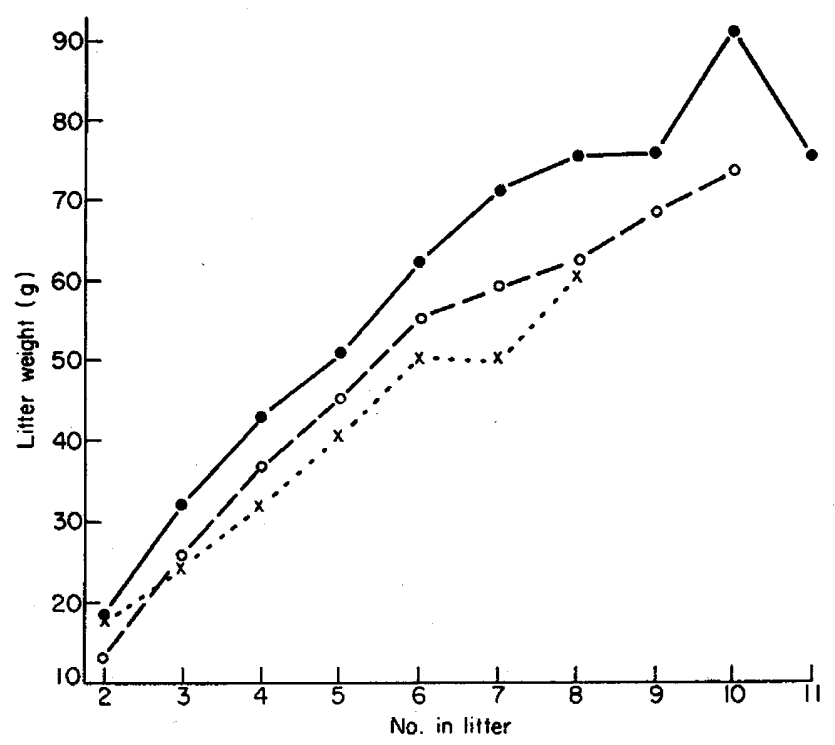

TexT-EIG. 3. As Text-fig. 1, litters aged 21 days. 
weaning is, however, unsatisfactory when the groups compared differ also in the distribution of litter size. Body weight at weaning tends to decline with increasing litter size, evidently owing to competition for milk; but the decline begins only above a certain litter size (Falconer, 1947; Bateman, 1957), which varies with genotype and environment. Text-figure 4 gives mean body weights at 3 weeks in relation to litter size at that age. The new stock did not display any

TABLE 2

PERCENTAGE LOSSES OF YOUNG AND LITTERS OF A2G/Tb MIGE

\begin{tabular}{|c|c|c|c|}
\hline & No. born & 0 to 10 days* & 10 to 21 days* \\
\hline $\begin{array}{l}21^{\circ} \mathrm{C} \\
\text { Young } \\
\text { Litters }\end{array}$ & $\begin{array}{l}824 \\
126\end{array}$ & $\begin{array}{l}13 \cdot 3 \\
10 \cdot 3\end{array}$ & $\begin{array}{l}1.9 \\
0.8\end{array}$ \\
\hline $\begin{array}{l}-3^{\circ} \mathrm{C}: \text { new stock } \\
\text { Young } \\
\text { Litters }\end{array}$ & $\begin{array}{r}205 \\
47\end{array}$ & $\begin{array}{l}22 \cdot 0 \\
21 \cdot 3\end{array}$ & $\begin{array}{l}8 \cdot 8 \\
4 \cdot 3\end{array}$ \\
\hline $\begin{array}{l}-3^{\circ} \mathrm{C}: \text { old stock } \\
\text { Young } \\
\text { Litters }\end{array}$ & $\begin{array}{l}681 \\
107\end{array}$ & $\begin{array}{l}9 \cdot 0 \\
6 \cdot 5\end{array}$ & $\begin{array}{l}1.9 \\
1.9\end{array}$ \\
\hline
\end{tabular}

* Each percentage is of the total born.

TABLE 3

INDIVIDUAL BODY WEIGHTS OF A2G/Tb MICE

\begin{tabular}{|c|c|c|c|c|}
\hline & \multirow{2}{*}{$\begin{array}{l}\text { No, of } \\
\text { mice }\end{array}$} & \multirow{2}{*}{$\begin{array}{c}\text { Body } \\
w t(g)\end{array}$} & \multicolumn{2}{|c|}{ Regression } \\
\hline & & & $b$ & $\mathbf{P}<$ \\
\hline $21^{\circ} \mathrm{C}$ & $\begin{array}{ll}\text { 중 } & 264 \\
+ & 205\end{array}$ & $\begin{array}{l}9 \cdot 6 \pm 0 \cdot 14 \\
9 \cdot 5 \pm 0 \cdot 13\end{array}$ & $\begin{array}{l}-0.84 \pm 0.12 \\
-0.72 \pm 0.11\end{array}$ & $\begin{array}{l}0.05 \\
0.05\end{array}$ \\
\hline $\begin{array}{l}-3^{\circ} \mathrm{C}: \\
\text { new stock }\end{array}$ & $\begin{array}{ll}\delta & 74 \\
\$ & 69\end{array}$ & $\begin{array}{l}7.9 \pm 0.23 \\
7.8 \pm 0.21\end{array}$ & 二 & - \\
\hline $\begin{array}{l}-3^{\circ} \mathrm{C}: \\
\text { old stock }\end{array}$ & $\begin{array}{ll} & 228 \\
\text { o } & 236\end{array}$ & $\begin{array}{l}8 \cdot 8 \pm 0 \cdot 12 \\
8 \cdot 6 \pm 0 \cdot 11\end{array}$ & $\begin{array}{l}-0.43 \pm 0.09 \\
-0.59 \pm 0.06\end{array}$ & $\begin{array}{l}0.1 \\
0.01\end{array}$ \\
\hline
\end{tabular}

Means, and regression coefficients of body weight on litter sizes above five, with their standard errors.

effect of litter size on body weight: if the four litters at extreme sizes are ignored, the rest of the curve, which covers litter sizes from three to six, is close to a horizontal straight line. The other two classes similarly gave no evidence of an effect over this range of litter sizes; but the curves for larger litters take the expected form. Table 3 gives estimated linear regressions of body weight at 3 weeks on number in a litter, for litter sizes above five.

\section{The wild mice}

The relationship of litter size with weight at weaning was further examined in the breeding record of wild mice; these mice belonged to a separate enquiry (Barnett et al., 1971). Text-figure 5 is based on their unpublished material. 


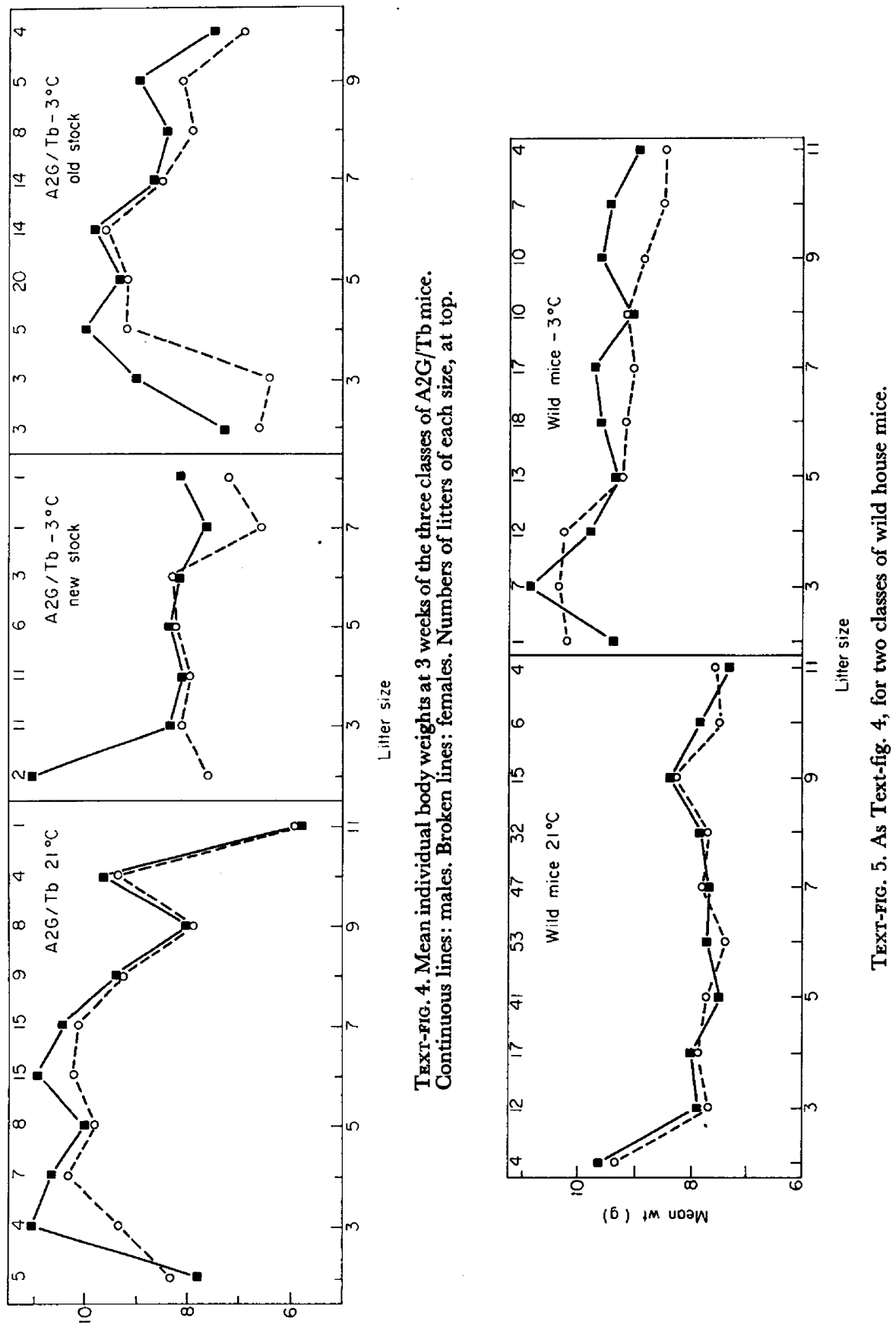

(5) im udaw. 
At $21^{\circ} \mathrm{C}$, there was no evidence of an effect of litter size on 3-week body weight, over the whole range of litter sizes from three to eleven. At $-3^{\circ} \mathrm{C}$, mean weights were, unexpectedly, higher than at $21^{\circ} \mathrm{C}$; this was probably due to the high nestling mortality at this temperature, and superior survival of the heavier mice. In the adverse conditions of the cold environment, there was evidence of an effect of litter size on growth in the nest. There was a regression of the body weight at 3 weeks on litter size, both of males $(b=-0.145 \pm 0.054 ; P<0.05)$ and of females $(b=-0.232 \pm 0.038 ; P<0.001)$.

\section{The $C 57 B L / T b$ mice}

Table 4 summarizes observations on the $\mathrm{G} 57 \mathrm{BL} / \mathrm{Tb}$ mice. Litter size was affected by cold, as was that of the A2G/Tb new stock. Mortality was low: only

TABLE 4

IITTER NUMBER, SIZE AND WEIGHT OF C57BL/Tb MICE AND MIXED STOCK

\begin{tabular}{|c|c|c|c|}
\hline & 0 days & 10 days & 21 days \\
\hline $\begin{array}{l}\text { C57BL/Tb, } 21^{\circ} \mathrm{C} \\
\text { No. of litters } \\
\text { Size } \\
\text { Weight }\end{array}$ & $\begin{array}{c}78 \\
7 \cdot 2 \pm 0 \cdot 21 \\
10 \cdot 0 \pm 0.32\end{array}$ & $\begin{array}{c}77 \\
7 \cdot 1 \pm 0 \cdot 22 \\
34 \cdot 1 \pm 1 \cdot 03\end{array}$ & $\begin{array}{c}77 \\
6.9 \pm 0.20 \\
49.4 \pm 1.61\end{array}$ \\
\hline $\begin{array}{l}\text { C57BL/Tb, }-3^{\circ} \mathrm{C} \\
\text { No. of litters } \\
\text { Size } \\
\text { Weight }\end{array}$ & $\begin{array}{c}77 \\
5 \cdot 8 \pm 0 \cdot 26 \\
8 \cdot 2 \pm 0.33\end{array}$ & $\begin{array}{c}72 \\
5 \cdot 7 \pm 0 \cdot 24 \\
30 \cdot 4 \pm 1 \cdot 17\end{array}$ & $\begin{array}{c}71 \\
5 \cdot 5 \pm 0 \cdot 23 \\
44 \cdot 3 \pm 1 \cdot 62\end{array}$ \\
\hline $\begin{array}{l}\text { Mixed, } 21^{\circ} \mathrm{C} \\
\text { No. of litters } \\
\text { Size } \\
\text { Weight }\end{array}$ & $\begin{array}{c}71 \\
9 \cdot 1 \pm 0 \cdot 46 \\
15 \cdot 2 \pm 0.72\end{array}$ & $\begin{array}{c}68 \\
9.0 \pm 0.44 \\
56.0 \pm 0.65\end{array}$ & $\begin{array}{c}65 \\
8 \cdot 7 \pm 0.40 \\
93 \cdot 2 \pm 3.59\end{array}$ \\
\hline $\begin{array}{l}\text { Mixed }-3^{\circ} \mathrm{C} \\
\text { No. of litters } \\
\text { Size } \\
\text { Weight }\end{array}$ & $\begin{array}{c}62 \\
8 \cdot 0 \pm 0 \cdot 36 \\
12 \cdot 0 \pm 0.53\end{array}$ & $\begin{array}{c}59 \\
7 \cdot 3 \pm 0.39 \\
42 \cdot 7 \pm 1 \cdot 83\end{array}$ & $\begin{array}{c}59 \\
7 \cdot 2 \pm 0 \cdot 38 \\
69 \cdot 2 \pm 3 \cdot 02\end{array}$ \\
\hline
\end{tabular}

Litter sizes and weights expressed as Means \pm S.E.

$7.8 \%$ of litters were lost, even at $-3^{\circ} \mathrm{C}$. The main distinctive feature of these mice was the absence of an effect of cold on litter weights. Mean litter weight at 3 weeks in the cold was $90 \%$ of that of the controls. The curve of 3-week litter weight against number in litter at $-3^{\circ} \mathrm{C}$ did not diverge from that at $21^{\circ} \mathrm{C}$ (Text-fig. 6). There is a similar absence of effect of cold on adult body weight of this strain (Barnett \& Scott, 1963).

\section{The mixed stock}

Table 4 also gives some of the findings from the mixed stock. These genetically heterogeneous mice were more fertile and heavier than either inbred strain, but otherwise showed a pattern of litter weights similar to that of A2G/Tb (Textfigs. 7 and 8). There was an effect of temperature on the weights of litters at each age $(P<0.05,0.01,0.05)$. 


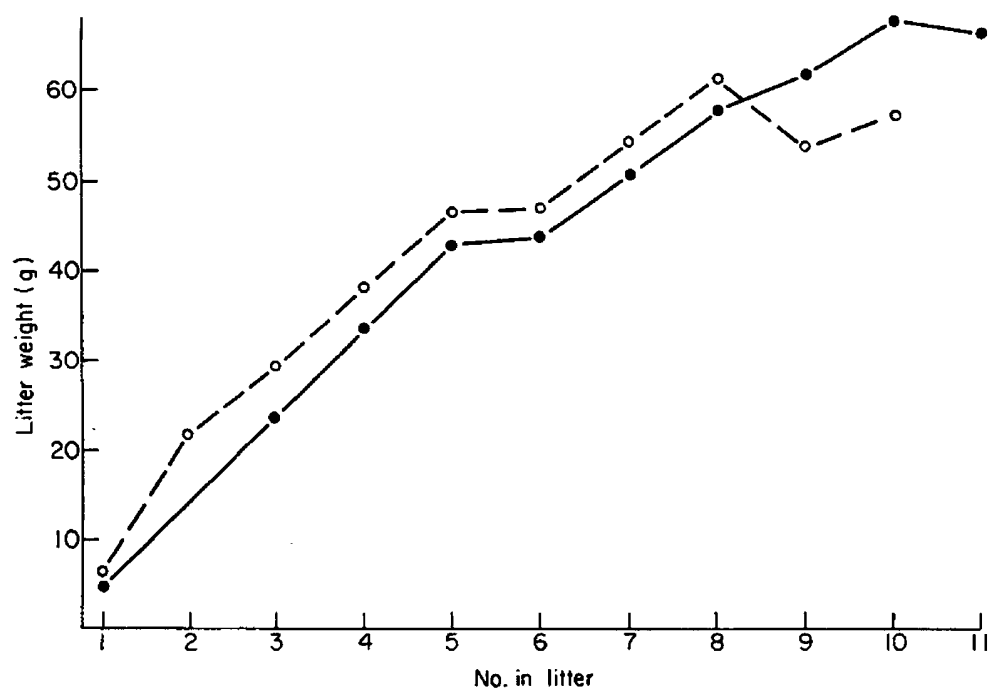

TExт-нio. 6. As Text-fig. 1, for C57BL/Tb, at 21 days.

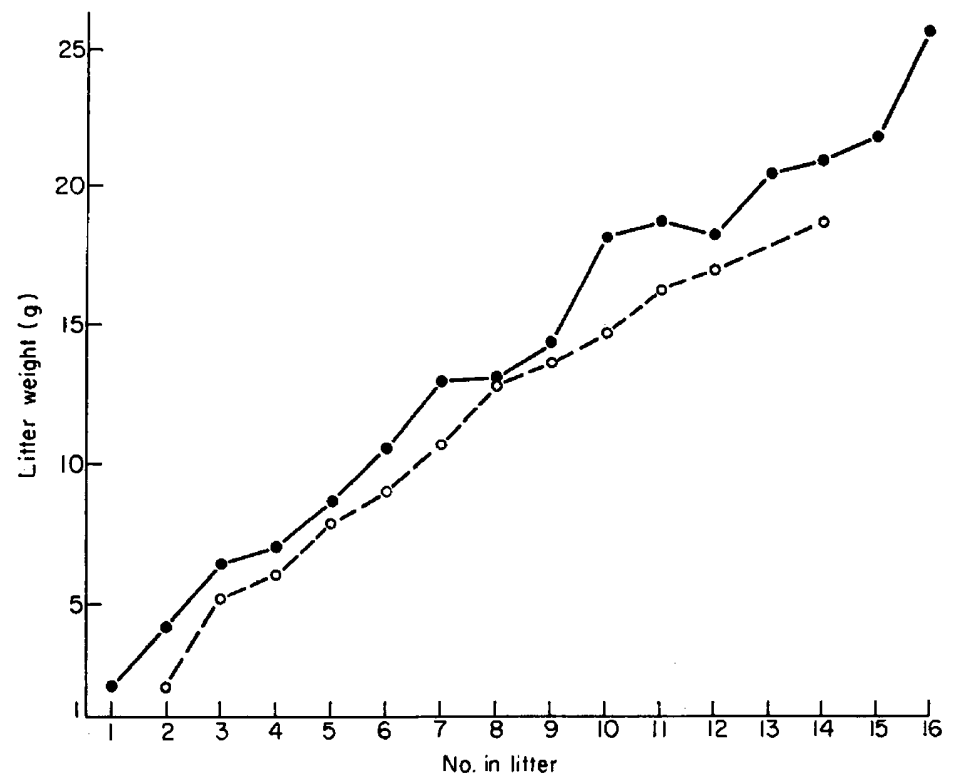

Text-gig. 7. As Text-fig. 1, for mixed stock at birth. 


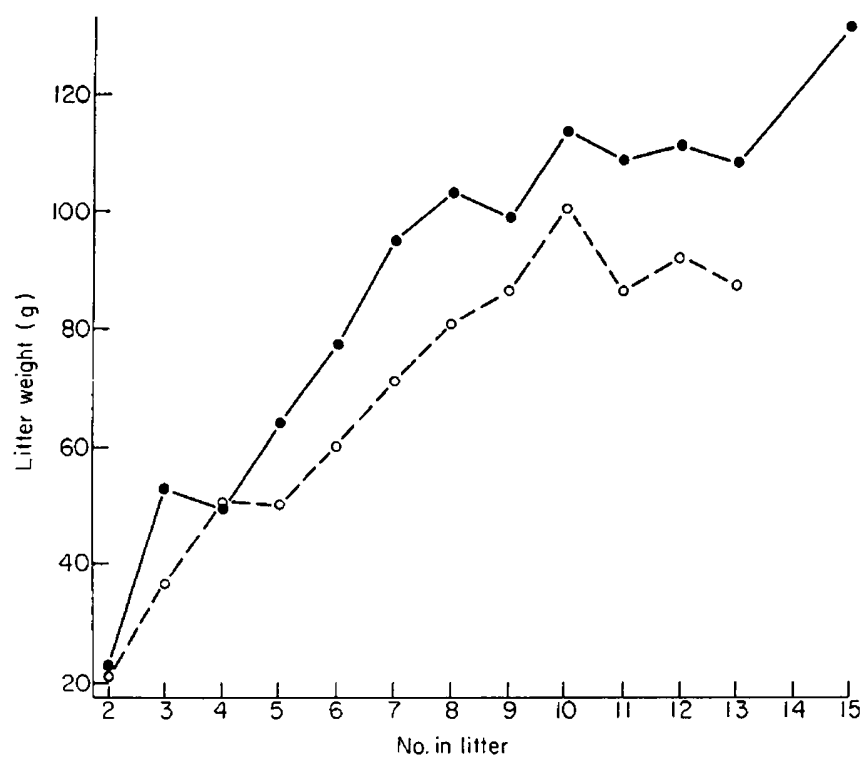

TexT-FIG. 8. As Text-fig. 1, for mixed stock at 21 days.

\section{DISCUSSION}

Two obvious criteria of the efficiency of a lactating female are the survival of her young, and their growth. The two may not be positively correlated. Mirone, Panzarella \& Cerecedo (1948) have referred to the high death rate of mice during the first 4 days after birth, and attribute these deaths to conditions in the uterus. They give evidence that uterine deficiency need not be accompanied by inadequate lactation. Barnett \& Neil (1971) cross-fostered litters of the three classes of $A 2 \mathrm{G} / \mathrm{Tb}$ mice: the survival rate of the fostered young in the nest reflected their true parentage, that is, the uterine environment, but their growth to weaning was determined by foster-parentage, that is, by conditions in the nest (including milk supply). These authors, and Barnett (1965), also discuss more fully the peculiarities of the $A 2 \mathrm{G} / \mathrm{Tb}$ mice bred for many generations in the cold environment.

Nestling mortality is usually expressed as the percentage of young that die before weaning; but, both in the present study and in that on fostered mice, nearly all deaths resulted from the loss of whole litters. The important unit is evidently not the individual mouse but the litter. Like those reported by Mirone et al. (1948), these deaths occurred early. On present evidence, therefore, mice produce two classes of litters, viable and non-viable. The fluctuating properties of the uterine environment which influence viability need investigation. Whatever they are, their effect on the A2G/Tb new stock was about double that on the controls.

Since there is little mortality within viable litters, litter size is largely determined at birth. As previously shown (Barnett, 1965), litters are usually smaller at $-3^{\circ} \mathrm{C}$ than at $21^{\circ} \mathrm{C}$. Although the sizes of $\mathrm{A} 2 \mathrm{G} / \mathrm{Tb}$ litters at birth were influenced by the cold, their weights at a given litter size were not (Text-fig. 1). 
Hence mean individual birth weight was not affected by environmental temperature. The new stock, instead of having some undersized young in large litters, had no large litters. A similar absence of large litters at $-3^{\circ} \mathrm{C}$ was recorded by Barnett \& Coleman (1960) among very fertile $\mathrm{F}_{1}$ mice produced by crossing strains C57BL and A2G.

The main findings of the present work concern body weight between birth and weaning, and especially the influence of litter size on postnatal growth. A simple hypothesis is of a negative regression of individual weight at 21 days on number in litter. The slope of the regression line could then be regarded as a measure of competition among litter mates, presumably for milk (Ashoub, Biggers, McLaren \& Michie, 1958). In fact, this model is not appropriate for two reasons. (i) Litters with few members do not conform to it. Among those who have observed this are MacDowell, Gates \& MacDowell (1930) and Falconer (1947) for mice, and Edwardson \& Eayrs (1967) for rats. Evidently, a female with a litter of only one or two fails to produce a normal amount of milk per suckling; for our old-stock females, even three sucklings may not have been enough stimulus (Text-fig. 4). (ii) Over a certain range, the curve of individual weight on litter size tends to form a plateau; this is especially well illustrated by the A2G/Tb new stock (Text-fig. 4) and the wild mice (Textfig. 5).

The modal litter size for each class of mice falls within the plateau. Hence most litters were of such a size that (a) there were enough sucklings for an optimum effect on lactation, (b) there were not so many sucklings that there was serious competition among them. These statements apply particularly to the wild mice in the warm environment. Evidently, litter size is regulated so that it tends towards an optimum for growth in the nest. This conforms with the hypothesis of Lack (1954) on the evolution of reproductive rates.

We have, then, evidence of the regulation of two properties of litters: their survival, and their size; the latter, however, is controlled only imperfectly. Since both survival and litter size are largely determined before birth, it is in the uterine environment that the regulating factors must be sought.

\section{AGKNOWLEDGMENTS}

We are grateful to the Medical Research Council and the Royal Society for grants in aid of this research, and to Dr M. J. Little for help with the statistical analysis.

\section{REFERENCES}

Ashoub, M. R., Biggers, J. D., MaLaren, A. \& Mighie, D. (1958) The effect of the environment on phenotypic variability. Proc. $R$. Soc. B, 148, 192.

Barnetr, S. A. (1956) Endothermy and ectothermy in mice at $-3^{\circ} \mathrm{C}$. F. exp. Biol. 33, 124.

BarnetT, S. A. (1965) Adaptation of mice to cold. Biol. Rev. 40, 5.

Barnett, S. A. \& Coleman, E. M. (1960) 'Heterosis' in $\mathrm{F}_{1}$ mice in a cold environment. Genet. Res. 1, 25.

BARnetT, S. A. \& NeIL, A. C. (1971) Growth and reproduction of mice cross-fostered between parents reared at different temperatures. F. Physiol., Lond. 215, 655.

BarnetT, S. A. \& ScotT, S. G. (1963) Some effects of cold and of hybridity on the growth of mice. 7. Embryol. exp. Morph. 11, 35 .

Barnett, S. A., Smart, J. L. \& Stoddart, R. C. (1971) Total reproductive performance of captive house mice at two temperatures. F. Zool., Lond. 163, 443. 
Barnett, S. A. \& Widnowson, E. M. (1965) Organ-weights and body-composition in mice bred for many generations at $-3^{\circ} \mathrm{C}$. Proc. $R$. Soc. $\mathrm{B}, 162,502$.

Bateman, N. (1957) Some physiological aspects of lactation in mice. F. agric. Sci., Camb. 49, 60.

BRUce, H. M. \& PARkes, A. S. (1949) Feeding and breeding of laboratory animals. 9. A complete cubed diet for mice and rats. F. Hyg., Camb. 47, 202.

EDWARDSON, J. A. \& EAYRs, J. T. (1967) Neural factors in the maintenance of lactation in the rat. 7. Endocr. 38, 51.

Falconer, D. S. (1947) Milk production in mice. J. agric. Sci., Camb. 37, 224.

GRÜNEBERG, H. (1952) The genetics of the mouse. Nijhoff, The Hague.

LACK, D. (1954) The evolution of reproductive rates. In: Evolution as a Process. Eds. J. Huxley, A. C. Hardy and E. B. Ford. Allen \& Unwin, London.

MacDowell, E. G., Gates, W. H. \& MacDoweld, C. G. (1930) The influences of the quantity of nutrition upon the growth of the suckling mouse. F. gen. Physiol. 13, 529.

Mirone, L., Panzarella, F. P. \& Gerecedo, L. R. (1948) A new method of reporting data on reproduction and lactation in the mouse. Science, N.Y. 108, 139.

Stoddart, R. C. (1966) Ice blocks as water supply for mice at $-3^{\circ}$ C. F. Inst. Anim. Tech. 17, 158. 